\title{
Corporate Governance and Leverage Implications on Firms' Profitability, Cash Flows and Value in Nigeria
}

\author{
Ejoh, Ndifon Ojong (Ph.D.) \\ Associate Professor of Accounting \& Finance, Department of Accountancy, \\ Cross River University of Technology, Calabar, Nigeria \\ Oko, Sylvanus Ushie (Ph.D) \\ Senior Lecturer, Department of Accountancy, \\ Cross River University of Technology, Calabar, Nigeria \\ Okpa, Friday Asibong \\ Postgraduate Student, Department of Accountancy, \\ Cross River University of Technology, Calabar, Nigeria
}

\begin{abstract}
The paper examines the implications of Corporate Governance and leverage on firm profitability (ROA), value (MPS) and cash flows (FCF). The study utilized the agency, stewardship and free cash flow theories. The correlation research design was employed and data collected from ten (10) listed manufacturing firms in Nigeria between the period 2009-2018. The data was analysed for descriptive and correlation properties, with the research hypotheses tested through regression analysis. The results of the study indicates that independent boards have significant negative influence on debt usage, board size does not have a significant effect on debt capital, CEO duality positively impacts the usage of debt financing. The results also indicate that independent boards (BIND) have significant impact on ROA, FCF and MPS, BSIZE is found to exert no statistically significant impact on the financial performance variables, CEO duality negatively impacts both FCF and MPS of the sampled manufacturing firms in Nigeria. Furthermore, the impact of DEBT on ROA and FCF are found to be negative, with the negative effect on ROA being statistically insignificant at the 0.05 level $(-0.015,(0.6846))$, and the negative effect on FCF being statistically significant at the 0.05 alpha level. The research concludes that the research therefore upholds that capital structure, corporate governance board characteristics and financial performance of manufacturing firms listed on the NSE are significantly related at the 0.05 level. The study recommended that the role of the CEO and board chairman be separated and current debt levels in the manufacturing industry be maintained.
\end{abstract}

Keywords: Corporate Governance, Leverage, Firm Profitability, Firm Cash Flows, Firm Value

DOI: $10.7176 /$ RJFA/10-24-04

Publication date: December $31^{\text {st }} 2019$

\section{INTRODUCTION}

Sound corporate governance principles are the foundation upon which the trust of investors and lenders is built. Basically, the fundamental perception and understanding of the field of corporate governance originated from the fact that there are potential problems associated with separation of ownership and control. This is inherent in the modern corporate form of organization with a set of institutional and market mechanisms that induce selfinterested managers (controllers) to maximize the value of the residual cash-flow of the firm on behalf of its shareholders (the owners). This conflict within the firms leads to distortion in corporate policy choices and lower corporate performance.

Good governance is characterized by transparency, accountability, board size, board composition, board independence, disclosure and compliance. Separation of ownership and control in firms is common in the modern-day business environment as more firms are listed on stock exchanges as public firms. However, this separation creates serious tension between the owner of a firm and the managers. Managers who are in power may have the motivation to transfer wealth in terms of bonus or other benefits at the expense of the owners to get dividend (Watts \& Zimmerman,1986). Also, Managers are positioned to opportunistically manage capital structure decision to maximize their utility at the expense of stakeholders. Managerial self-interests in the firm may entice managers to prefer and opt for equity rather than debt. Because creation of debt reduces the agency costs of free cash flow by reducing the amount available to managers since they are bound to repay the interest payments. If they spend the free cash on more risky action, the probability that the repayment schedule will be met decreases.

Corporate governance mechanisms provide the basis for a stable and productive business environment which protects the interests of internal and external stakeholders. This has become an important and well debated issue in recent years. Therefore, good corporate governance practices may have significant influence on the 
strategic decisions of a company, e.g. external financing that are taken at board level. This makes corporate governance variables like, ownership concentration, institutional investors and board composition to have direct impact on capital structure decisions of corporate firms.

The intention of managers is to maintain viability in the firm thus reducing the level of debt since increased debt leads to high bankruptcy cost. Managers pursue their own interest to reduce the debt level in capital structure at the expense of the shareholders. Also, the presence of institutional investors in a company helps it to raise long term finance at an advantageous cost. In the first place, these institutional investors act as a source of long term debt as they are willing to provide debt to a company over whose board they enjoy an influence. Secondly, these institutional investors serve as an effective monitoring device over the company's strategic decisions. They bring down the company's agency costs, and, also reduce managerial opportunism. This gives confidence to general public and other lenders - resulting in favourable terms of borrowing by the company. Institutional investors are large investors such as, insurance companies, banks and investment companies. The presence of non-executive directors means those directors that have no executive post in firm; thus, their supervisory performance highly helps to reduce the conflict between shareholders and firms' directors. Also, their presence on the company's board gives signal to the market that company is being monitored efficiently so lenders consider it credit worthy. In turn, this makes it easier for the company to raise long term fund through debt financing.

Given the fact that corporate governance and leverage are paramount to the overall success of a firm, this study therefore examines the implications of corporate governance mechanisms and leverage on of the performance of foods and beverages firms in Nigeria.

The following null hypotheses are formulated for testing:

Ho1: There is no significant relationship between governance mechanisms and leverage of manufacturing firms in Nigeria

Ho2: Governance mechanisms and leverage have no significant effect on financial performance of manufacturing firms in Nigeria

\section{LITERATURE}

\subsection{Theoretical Framework}

The following theories underpin the study;

\subsubsection{Agency Theory}

This theory is considered as a dominant role to explain the role of governance, CEO, and board directors on firm performance. Zahra and Pearce (1989) reviewed research papers and synthetized them into main rule in order to explore this relationship. In term of agency theory, the principal and agent are shareholders and directors respectively. Their theory presented that there is inconsistency between the benefit of owners and managers based on the attributes of four characteristics as discussed legalistic perspective. Having similar view with Zahra and Pearce (1989) on agency theory, Davis, Schoorman and Donaldson (1997) indicated more clearly that agency theory refers to the conflict between the goal of principal as owners and agent as managers. In a particular company, shareholders allocate their wealth investing on the asset of corporations and they authorize managers to operate the firms. The principal has tendency to maximize the utility of shareholder in the long- run. By contrast, the agents usually operate firms for their individual interests. Pfeffer (1972) indicated that most companies meet the change in business environment is changing size and board composition measured by percentage of outside directors and ownership. The percentage of outside director helps firms attract outside capital which also influences the firm performance. With external capital, the firm can take advantage of cheaper capital from the outside and reduce costs. In addition, organizational environment is also reflected through a board size. The advantages of larger size board are first, more diversified in handling problems and second, increasing the impact of company to society due to the relationship of members in board. Therefore, firms with many directors will exploit more resources from the outside than the others in order to make their performance better.

\subsubsection{Stewardship Theory}

In contrast to agency theory, Davis, Schoorman and Donaldson (1997) examined the new approach to the relationship between the benefit of shareholders and managers, which is developed based on psychological and sociological concepts. The interests of individual and organization are mixed and managers operate companies to maximize utility. The cooperative behaviors are not traded off for self-behaviors because, in term of stewardship theory, the thoughts and activities of directors are consistent with the performance of companies. Therefore, the steward seeks to get the objectives and development of firms. The differences between the stewardship and agency are that the agency theory focuses on extrinsic satisfaction which can be measured by market value and the other refers to intrinsic satisfaction which can be motivation, achievement or reputation. Moreover, the manager in stewardship perspective realizes that by working for the high performance of organization, the 
personal utility can be met. Additional new information from this theory is focusing on the role of structure rather than the monitor and control. Particularly, stewardship concepts consider structure of the board affecting the firm performance significantly.

\subsubsection{Free Cash Flow Theory}

According to free cash flow theory (Jensen, 1986), leverage itself can also act as a monitoring mechanism and thereby reduces the agency problem hence increasing firm value by reducing the agency costs of free cash flow. There are some consequences derived if a firm is employing higher leverage level in that managers of such firm will not be able to invest in non-profitable new projects, as doing so the new projects might not be able to generate cash flows to the firm, hence managers might fail in paying the fixed amount of interest on the debt or the principal when it's due. It also might cause the inability to generate profit in a certain financial year that may result in failing to pay dividends to firm shareholders.

Leverage might not only be able to reduce the agency costs of free cash flow, but also can increase the efficiency of the managers. This is due to the debt market that might function as a more effective capital market monitoring. In addition, in order to obtain the debt financing, managers must show their abilities and efficiencies in managing the firm. Empirically, it has been proven that leverage proxied by bank lenders, can be substitute monitoring mechanism especially in weak CG firms, but not in the more active merger environments.

\subsection{Empirical Review}

\subsubsection{Corporate governance mechanisms and capital structure}

Claessens et al. (2002) maintain that better corporate governance frameworks benefit firms through greater access to financing, lower cost of capital, better performance and more favourable treatment of all stakeholders. Corporate governance affects the development and functioning of capital markets and exerts a strong influence on resource allocation. Corporate governance correlates with the financing decisions and the capital structure of firms (Abor, 2007).

Wen et al. (2002) posit that larger board size is associated with higher debt, either to improve the firm's value or because the larger size prevents the board from reaching a consensus on decisions, indicating a weak corporate governance system. Anderson et al. (2004) further indicate that larger board size results in lower cost of debt, which serves as a motivation for using more debt and this has been confirmed by Abor (2007) who concludes that capital structure positively correlates with board size, among Ghanaian listed firms. In relation to the presence of external directors on the board, Wen et al. (2002) conclude that the presence of external directors on the board leads to lower leverage, used by the firm, due to their superior control.

Guo, Ding \& Sun (2010) investigated the effect of ownership structure on leverage levels. They used 365 companies from 1997 to 2009. Panel multiple regression was used for data analysis. Their research findings confirmed negative effect of ownership on leverage. Also, further investigation showed that change in the company leverage, positively associated with level of ownership concentration.

Rehman et al. (2010) investigated the relationship between corporate governance and capital structure of randomly selected 19 banks of Pakistan from 2005-2006. Panel multiple regression for analysis was used. They found a positive relationship between board size and capital structure

Saad (2010) used a sample of 126 Malaysian publically listed companies from four industries (i) consumer products, (ii) industrial products, (iii) trading/services, and (iv) plantations for the period from 1998 to 2006 , through multiple regression analysis. The results show a positive relationship between board size and capital structure and a negative relationship between duality and capital structure. Also, Berger \& Diatti (2003) tested the corporate governance theory and predicted that leverage affects agency cost and thereby influence firm performance, and they revealed that the data on US banking was consistent with the theory.

Abor \& Biekpe (2007) examined the relationship between corporate governance and capital structure of Ghanaian Small and Medium Enterprises using multivariate regression analysis. The results provided evidence about negative relationship between corporate governance and capital structure decisions. Our study used a panel multiple regression technique of data analysis in testing and examining the hypothesis under study.

Otnet (2006) conducted a study on the relationship between corporate governance and capital structure using Jordanian companies ${ }^{\text {ee }}$ data while assuming ownership structure as a proxy of corporate governance. The work indicates that the agency cost arises due to internal and external set of mechanism and ownership structure has positive and negative impact on the capital structure. Firstly, a negative relation between ownership structure and capital structure is due to short term financing. Secondly, a positive relationship between ownership structure and capital structure is due to sustainability in financing and enforcement of block holders to avail the opportunity of high debt.

Wen et al. (2002) found the relationship between corporate governance and capital structure by analyzing the data of Chinese listed companies. The study revealed that, due to strict rules and regulations, managers of the Chinese firm do not employ debt to keep the risk of default at low level. In addition, three reasons for employing low debt are; the small numbers of directors in the firms, the large numbers of outside directors in the board of 
directors and the attractive tenure, salary, and bonus of the CEO.

Hussainy and AlJifri (2009) examined the relationship between the corporate governance mechanisms and corporate capital structure. They divided these mechanisms into two types of internal and external mechanisms. The Sample consisted of 71 companies, using multiple regressions. The results of this study indicated that institutional investors on debt to equity ratio have a negative impact.

Abor (2007) in his study on how corporate governance affects capital structure by taking a sample of 22 firms listed on the Ghana Stock Exchange (GSE) during the six-year period (1998-2003) was found that there is a significantly negative relationship between board size and capital structure and opposite finding on the association between CEO duality and leverage where it implies that larger boards adopt low debt policy and $\mathrm{CEO}$ as the board chairman tend to employ high proportion of debt.

Wen, Rwegasira, \& Bilderbeek, (2002) on corporate governance and capital structure decisions of the Chinese listed firms found that managers tend to pursue lower financial leverage when they face strong corporate governance from the board. However, their finding only shows a significant value of board composition and CEO tenure and insignificant results for board size and fixed CEO compensation.

Bodaghi and Ahmadpour (2010) collected data from 50 Iranian firms listed at Tehran Stock Exchange to test the relationship between corporate governance and capital structure. They found a negative relationship between board size and debt to equity ratio. They found that CEO duality does not significantly influence corporate financing behavior.

Suto (2003) described the relationship between corporate governance and capital structure before and after the financial crises, using the agency cost approach. The study analyzes the time series and cross-sectional data obtaining from KLSE, by using different proxy variables for capital structure and corporate governance. The result showed that the commitment in banks for lending and borrowing causes to increase the debt ratio. On the other hand, increase in ownership does not affect corporate management. Further, the study investigates the foreign ownership reduces the agency cost, as well, high debt ratio attracts excessive investments.

\subsubsection{Corporate governance and leverage effects on mechanisms and financial performance.}

Corporate governance of firms seems to be more important than other industries because the banking sector plays a crucial financial intermediary role in any economy, particularly in developing countries. Poor corporate governance of the banks can drive the market to lose confidence in the ability of a bank to properly manage its assets and liabilities, including deposits, which could in turn trigger a liquidity crisis and then it might lead to economic crisis in a country and pose a systemic risk to the society at large (Alexander, 2006; Garcia-Marco \& Robles-Fernandez, 2008).

Jandik and Rennie (2008) in transition economies tries to evaluate the evolution of corporate governance practices and firm performance in a Czech manufacturing company. The results show that adoption of these practices (that included issues like concentration of ownership and improvements in monitoring) led to superior financial performance. There are several reasons why enhanced corporate governance may not lead to lower financial performance ratios as a result of the associated costs. Good governance practices can lead to improvements in terms of the decision making process of the company.

Friend and Lang (2008) examine that shareholders, having high concentration in firms, play an important role to control and direct the management to take keen interest in benefit of the concentration group. However, corporate governance command also allows shareholders to direct the management for betterment of their investment.

Driffield et al. (2007) stated that higher ownership concentration has a positive impact on capital structure and firm value. In the other case, lower ownership concentration, the relationship depends upon the strictness of managerial decision making which enforce to bring change in the capital structure. Gompers et al. (2003) analyzed the relationship between corporate governance, long-term equity returns, firm value and accounting measures of performance, while Rob et al. (2004) found combined relationship between corporate governance, firm value and equity returns.

Johnson et al. (2000) and Durnev and Kim (2003) suggest that insiders expropriate more when the market is bad, and take less when the market is good. Corporate governance mechanisms assure investors in corporations that they will receive adequate returns on their investments. If these mechanisms did not exist or did not function properly, outside investors would not lend to firms or buy their equity securities. Overall, economic performance would likely suffer because many good business opportunities would be missed and temporary financial problems at individual firms would spread quickly to other firms, employees and consumers. Previous evidence suggests that corporate governance has a positive influence over corporate performance.

Gemmill and Thomas (2004) concluded in their respective study that there is a positive relationship between good corporate governance practices and firm value. Corporate governance may have an influence on the level of disclosure (Haniffa and Cooke, 2002) as well as timeliness of reporting, especially as it is the board of directors that manages information disclosure in annual reports. The quantity of information and especially voluntary items disclosed in the annual reports and the time the information to be released, are influenced by the 
board of directors. Thus, referring back to agency theory, when the board of directors are independent of the management and observe their responsibility to be accountable and transparent to the shareholders or stakeholders, they will disclose on time all the relevant information, not just the mandatory ones but also the voluntary items (Mohd et al., 2008).

Nimalathasan \& Brabete (2010) pointed out capital structure and its impact on profitability: a study of listed manufacturing companies in Sri Lanka. The analysis of listed manufacturing companies shows that debt to equity ratio is positively and strongly associated to all profitability ratios (Gross Profit, Operating Profit \& Net Profit Ratios).

Brander and Lewis (2006) provide the theoretical framework that links capital structure, corporate governance and market structure. Contrary to the profit maximization objective postulated in industrial organization literature, these theories are similar to the corporate finance theory in that they assume that the firm's objective is to maximize the wealth of shareholders. Furthermore, market structure is shown to affect capital structure by influencing the competitive behavior and strategies of firms.

\section{RESEARCH METHODOLOGY}

\subsection{Design and Data}

This study adopts correlation research design. The sample of the study is ten (10) listed manufacturing companies that are quoted on the Nigerian stock exchange during the period 2009-2018. The two filters used to select the ten companies include: companies that made available their annual report of ten years to the Nigerian stock exchange and Fact Book. Again, companies that are listed on the Nigerian Stock Exchange before the period of the study, that is 2009 - 2018. The data filter is to ensure that the annual accounts of the companies under study are available and accessible. The data collected for the study include: total debt (short term and long term debt), equity, earnings before interest and tax, total asset, share prices, numbers of directors, non-executive directors, CEO duality.

In this research, multiple regression technique of data analysis is used in testing and examining the hypotheses of the study. The technique helps in assessing the relationship between corporate governance mechanisms, capital structure and financial performance of listed manufacturing firms in Nigeria which involves the data collected from secondary source.

\subsection{Model Specification}

To test hypothesis one, which examines the relationship between corporate governance mechanisms and capital structure, the following models are formulated:

$\operatorname{DEBT}_{\mathrm{t}}=\beta_{0}+\beta_{1} \mathrm{BIND}_{\mathrm{t}}+\beta_{2} \mathrm{BSIZE}_{\mathrm{t}}+\beta_{3} \mathrm{CEO}_{\mathrm{t}}+\rho$ Controls $+\varepsilon_{\mathrm{t}}$

$\mathrm{EQTY}_{\mathrm{t}}=\beta_{0}+\beta_{1} \mathrm{BIND}_{\mathrm{t}}+\beta_{2} \mathrm{BSIZE}_{\mathrm{t}}+\beta_{3} \mathrm{CEO}_{\mathrm{t}}+\rho$ Controls $+\varepsilon_{\mathrm{t}}$

Where: DEBT and EQTY denotes Debt capital structure and Equity capital structure respectively, which both are measures of capital structure. BIND, BSIZE and CEO are measures of governance mechanisms, with BIND denoting Board independence, BSIZE denoting board size and CEO denoting CEO duality, where the CEO is also the chairman of the board. Controls are variables such as Firm size (FSIZE), tangibility (TANG) and growth opportunities (GOP), which are used in prior scholarships as determinants of capital structure decisions.

To test hypothesis two, which examines the relationship between corporate governance mechanisms and financial performance, the following models are formulated:

ROA $_{t}=\beta_{0}+\beta_{1}$ BIND $_{t}+\beta_{2}$ BSIZE $_{t}+\beta_{3}$ CEO $_{t}+\beta_{4}$ DEBT $_{t}+\beta_{5}$ EQTY $_{t}+\rho$ Controls $+\varepsilon_{t}$

$\mathrm{FCF}_{\mathrm{t}}=\beta_{0}+\beta_{1} \mathrm{BIND}_{\mathrm{t}}+\beta_{2} \mathrm{BSIZE}_{\mathrm{t}}+\beta_{3} \mathrm{CEO}_{\mathrm{t}}+\beta_{4} \mathrm{DEBT}_{\mathrm{t}}+\beta_{5} \mathrm{EQTY}_{\mathrm{t}}+\rho$ Controls $+\varepsilon_{\mathrm{t}}$

MPS $_{\mathrm{t}}=\beta_{0}+\beta_{1}$ BIND $_{\mathrm{t}}+\beta_{2}$ BSIZE $_{\mathrm{t}}+\beta_{3} \mathrm{CEO}_{\mathrm{t}}+\beta_{4} \mathrm{DEBT}_{\mathrm{t}}+\beta_{5} \mathrm{EQTY}_{\mathrm{t}}+\rho$ Controls $+\varepsilon_{\mathrm{t}}$

Where: ROA, FCF and MPS are measures of financial performance with ROA denoting Returns on Assets (representing profitability), FCF denoting Free Cash Flow (representing cash flows), and MPS denoting Market Price of Shares (representing value). Controls refer to Firm size (FSIZE) and Firm age (FAGE), which are used in prior scholarships as determinants of firm financial performance. 
3.3 Variable Definition

The following variables are described in the study;

\begin{tabular}{|c|c|}
\hline Variables & Definitions \\
\hline \multicolumn{2}{|l|}{ RESEARCH VARIABLES } \\
\hline Profitability (ROA) & ROA is measured as net Income for the year deflated by total assets \\
\hline Free Cash Flow (FCF) & $\begin{array}{l}\text { FCF is expressed as operating cash flows minus capital expenditure. The } \\
\text { value is deflated by total assets }\end{array}$ \\
\hline $\begin{array}{l}\text { Market Price } \\
\text { Share (MPS) }\end{array}$ & $\begin{array}{l}\text { MPS is computed from annual Price (i.e. closing price of a share of common } \\
\text { stock on December 31). It is a measure of stock performance, usually } \\
\text { expressed in kobo. }\end{array}$ \\
\hline Debt capital (DEBT) & $\begin{array}{l}\text { DEBT is total debt obtained from the balance sheet, as the sum of short term } \\
\text { debt and long term debt. The value is deflated by total assets. }\end{array}$ \\
\hline Equity Capital (EQTY) & $\begin{array}{l}\text { EQTY is total equity obtained from the balance sheet as the sum of share } \\
\text { capital value, retained earnings, and other equity components. The value is } \\
\text { deflated by total assets. }\end{array}$ \\
\hline Board Independence (BIND) & $\begin{array}{l}\text { BIND represents independent directors, expressed as the percentage ratio of } \\
\text { non-executive directors over total directors. }\end{array}$ \\
\hline Board Size (BSIZE) & BSIZE represents total number of directors in a company's board. \\
\hline CEO duality (CEO) & $\begin{array}{l}\text { CEO represents the situation where the Chief Executive Officer (CEO) or } \\
\text { Managing Director (MD) of the company is also the Chairman of the Board } \\
(\mathrm{COB}) \text {. It is a dummy variable where } \mathrm{CEO}=1 \text { where this duality of roles } \\
\text { exists, and } \mathrm{CEO}=0 \text { otherwise. }\end{array}$ \\
\hline \multicolumn{2}{|l|}{ CONTROL VECTORS } \\
\hline Firm size (FSIZE) & FSIZE is measured as natural log of total assets \\
\hline Tangibility (TANG) & TANG is obtained as fixed assets deflated by total assets \\
\hline Growth potential (GOP) & GOP is measured as change (increase) in sales value \\
\hline Firm Age (FAGE) & FAGE is the number of years a firm has been incorporated \\
\hline
\end{tabular}

\section{RESULTS}

This section contains data presented in their descriptive statistics, to explain the properties and characteristics of the data and variables used in the research.

Table 1: Descriptive Statistics of Variables

\begin{tabular}{|c|c|c|c|c|c|c|c|c|}
\hline & ROA & MPS & DEBT & EQTY & BIND & BSIZE & CEO & FCF \\
\hline Mean & 0.12 & $249 \mathrm{k}$ & 0.197 & 0.453 & 0.64 & 8.324 & 0.183 & 0.384 \\
\hline STD & 0.182 & $217 \mathrm{k}$ & 0.39 & 0.263 & 0.14 & 2.517 & 0.39 & 0.323 \\
\hline Maximum & 0.793 & $1175 \mathrm{k}$ & 0.953 & 0.933 & 0.833 & 15 & 1 & 0.995 \\
\hline Minimum & -0.156 & $39 \mathrm{~K}$ & 0 & -0.711 & 0.333 & 6 & 0 & -0.217 \\
\hline Median & 0.082 & $150 \mathrm{k}$ & 0.104 & 0.465 & 0.667 & 8 & 0 & 0.126 \\
\hline
\end{tabular}

Table 1 provides statistics on the characteristics of average, standard deviation, maximum, minimum and median of the variables included in the study, which include profitability (ROA), Free Cash Flows (FCF), Firm Value (MPS), Debt Capital (DEBT), Equity Capital (EQTY), Board Independence (BIND), Board Size (BSIZE) and $\mathrm{CEO}$ duality (CEO). To alleviate the effects of spurious outliers, extreme values are limited in the statistical data, with ROA, DEBT, EQTY, FCF winsorized at $1 \%$ and $99 \%$.

The descriptive results reveal the following:

The result for ROA indicates an average value of 0.12 , with a standard deviation of 0.18 . The minimum and maximum values of ROA during the study period are 0.79 and -0.16 respectively for ROA. These values imply that the average profit of the sampled manufacturing companies stood at about $12 \%$ of total assets, with the highest profit being $79 \%$ of total assets, and the least profit being a loss of about $16 \%$ of total assets.

The descriptive results of firm value, measured using the market price of shares indicate that the average market price of manufacturing firm shares in the period studied are about 2.49 naira, with maximum price for the 
period under study amounting to about 11.75 naira, with the minimum price plummeting as low as 0.39 naira. The values of the shares are relevant to the analysis of this study.

The free cash flows descriptive statistics show that operating cash after capital expenditure are about 0.995 , -0.217 and 0.364 for maximum, minimum and average FCF respectively. The results indicate that average FCF are about $3.4 \%$ of total assets among manufacturing forms quoted on the NSE, with maximum and minimum FCF amounting to about 99.55 and $-21.7 \%$ of total assets. There are thus both positive and negative cash flows during the period, with a median FCF of about 12.6 percent of total assets in the period under study.

Similarly, the table shows total debt capital has an average of 19.7 percent of total assets. The maximum and minimum debt values are $95.3 \%$ and $0 \%$ of total assets. The results are interpreted to mean that overall, there are firm-year observations with extremely high debt capital, while some firm-year observations had no debt capital in its capital structure. The mean value of 19.7 percent indicate that overall, the debt capital usage among manufacturing firms listed in the NSE is relatively low, with a median value of about 10.4 percent of total assets. Overall, the values indicate that most sampled firms do not use more of debt capital.

The table further revealed an average value of 0.453 for equity capital. The value implies that about 45.3 percent of the sampled manufacturing companies had high amounts of equity capital, with the maximum and minimum equity capital during the study period being 93.3 percent and -71.1 percent of total assets. The negative percentage of minimum equity capital indicate that some firm-year observations had negative equity value, explained by accumulated losses eroding the positive equity values. The standard deviation of equity capital is 0.263

The descriptive results for board independence revealed an average value of 0.64 . The value implies that about 64 percent of the sampled companies had higher proportion of non-executive directors in their board, than executive directors. Overall, the maximum BIND is 83.3 percent explaining that some firms in the study sample had about $83.3 \%$ board independence, with the minimum board independence in the study period being about $33.3 \%$. The median and standard deviation scores are 0.667 and 0.14 , indicating that more than half of the sampled firms have independent boards made up of a greater proportion of or non-executive directors. The result is relevant to the study.

Data on board size reveals an average of 8.324, with maximum and minimum board size coming up to 15 and 6 respectively. The results stated above indicate that firms with the largest board have about 15 directors on their board, with the smallest board size being 6 directors. The average and median board size result indicate that majority of the board have directors above 8 directors, which is the median board size of the sampled firms. Overall, most manufacturing firms sampled in the study have large boards.

Finally, the result of CEO duality show that only about 18.3 percent of sampled firms practiced CEO duality, leaving about 81.7 percent of firms that separate the roles of the CEO and the chairman of the board.

\subsection{Data Analysis}

This section analyses the correlation results of all variables studied. The Pearson correlation coefficient, followed by the sig. $\mathrm{p}$ values \{in italics\} are expressed in the table below

Table 2: Correlations coefficient and ( $p$-values) of variables studied

\begin{tabular}{|c|c|c|c|c|c|c|c|c|}
\hline & ROA & DEBT & EQTY & BIND & BSIZE & CEO & MPS & FCF \\
\hline ROA & 1.0000 & & & & & & & \\
\hline & & & & & & & & \\
\hline DEBT & -0.0530 & 1.0000 & & & & & & \\
\hline & $\{0.6600\}$ & & & & & & & \\
\hline EQTY & 0.1068 & -0.0217 & 1.0000 & & & & & \\
\hline & $\{0.3752\}$ & $\{0.8573\}$ & & & & & & \\
\hline BIND & 0.2673 & -0.1647 & 0.2243 & 1.0000 & & & & \\
\hline & $\{0.0242\}$ & $\{0.0497\}$ & $\{0.0500\}$ & & & & & \\
\hline BSIZE & -0.2067 & 0.1444 & -0.1649 & 0.3490 & 1.0000 & & & \\
\hline & $\{0.067\}$ & $\{0.2295\}$ & $\{0.1695\}$ & $\{0.0029\}$ & & & & \\
\hline CEO & -0.0284 & 0.4424 & -0.2301 & 0.0681 & -0.1779 & 1.0000 & & \\
\hline & $\{0.8141\}$ & $\{0.0275\}$ & $\{0.0492\}$ & $\{0.5725\}$ & $\{0.1377\}$ & & & \\
\hline MPS & 0.3006 & -0.0190 & 0.5413 & 0.4287 & 0.0785 & -0.3014 & 1.0000 & \\
\hline & $\{0.0109\}$ & $\{0.8724\}$ & $\{0.0000\}$ & $\{0.0002\}$ & $\{0.5155\}$ & $\{0.0106\}$ & & \\
\hline FCF & 0.1236 & -0.3294 & 0.1635 & 0.5102 & 0.0789 & -0.4705 & 0.0252 & 1.0000 \\
\hline & $\{0.3082\}$ & $\{0.0054\}$ & $\{0.1763\}$ & $\{0.0367\}$ & $\{0.5161\}$ & $\{0.03511\}$ & $\{0.8358\}$ & \\
\hline
\end{tabular}

Table 2 presents correlation values between dependent and independent variables and the correlation among the independent variables themselves. These values are generated from Pearson Correlation output.

The relationship between firm financial performance variables and capital structure variables reveal that debt and equity capital structure have no significant relationship with ROA, with the DEBT-ROA correlation 
coefficient being $-0.053(p=0.660)$, and EQTY-ROA correlation coefficient being $0.107(p=0.385)$. While the DEBT-FCF correlation coefficient is negative and statistically significant $(\mathrm{r}=-0.329, p=0.005)$, the EQTY-FCF correlation coefficient is positive and insignificant $(\mathrm{r}=0.163, p=0.176)$. Again, while the DEBT-MPS correlation is negative and insignificant $(\mathrm{r}=-0.019, p=0.87)$, the EQTY-MPS correlation is positive and statistically significant $(\mathrm{r}=0.541, p=0.000)$.

Overall, debt capital is associated with lower cash flows, and equity related to increasing value of manufacturing firms.

The relation between financial performance variables and governance variables reveal the following results. The link between ROA and board characteristics is positive and significant for BIND ( $\mathrm{r}=0.267, p=0.024)$, negative and insignificant for BSIZE $(\mathrm{r}=-0.207, p=0.067)$, negative and insignificant for CEO duality $(\mathrm{r}=-0.028$, $p=0.814)$.

The link between FCF and board characteristics is positive and significant for BIND ( $\mathrm{r}=0.510, p=0.037)$, positive and insignificant for BSIZE $(\mathrm{r}=0.079, p=0.516)$, and negative and significant for CEO duality $(\mathrm{r}=-0.471$, $p=0.035)$.

The link between MPS and board characteristics is positive and significant for BIND $(\mathrm{r}=0.429, p=0.000)$, positive and insignificant for BSIZE $(\mathrm{r}=0.079, p=0.0515)$, and, negative and significant for CEO duality $(\mathrm{r}=-$ $0.301, p=0.011)$.

Overall, BIND is positively and significantly related with all financial performance proxies, with CEO duality being associated with reduced cash flows and market values.

The relation between capital structure variables and governance variables reveal the following results. The link between DEBT and board characteristics is negative and significant for BIND $(\mathrm{r}=-0.164, p=0.04)$, positive and insignificant for BSIZE $(\mathrm{r}=0.144, p=0.230)$, positive and significant for CEO duality $(\mathrm{r}=0.442, p=0.028)$. The link between EQTY and board characteristics is positive and significant for BIND $(\mathrm{r}=0.224, p=0.050)$, negative and insignificant for BSIZE $(\mathrm{r}=-0.165, p=0.170)$, negative and significant for CEO duality $(\mathrm{r}=-0.230$, $p=0.049$ ).

Overall, an independent board is associated with higher equity capital, and lower debt levels, which is the direct opposite of the dual CEO situation. Dual CEOs prefer higher debt levels and lower equity levels.

Among the proxies of financial performance, there appears to be a positive and significant relationship between ROA and MPS. Among the proxies of board characteristics, BIND is found to be positively and significantly related with BSIZE. Whereas, equity and debt which are the proxies of capital structure have no significant relationship from the Pearson correlation results in table 2.

Table 3: Cross Sectional Regression result for Hypothesis 1

\begin{tabular}{|c|c|c|}
\hline VARIABLES & PANEL 1 & PANEL 2 \\
\hline \multirow[t]{2}{*}{ Intercept } & 0.088 & 0.055 \\
\hline & $\{0.4461\}$ & $\{0.9855\}$ \\
\hline \multirow[t]{2}{*}{ BIND } & -0.209 & 0.775 \\
\hline & $\{0.0312\}$ & $\{0.0033\}$ \\
\hline \multirow[t]{2}{*}{ BSIZE } & -0.094 & -0.0448 \\
\hline & $\{0.4225\}$ & $\{0.5222\}$ \\
\hline \multirow[t]{2}{*}{ CEO } & 0.161 & -0.355 \\
\hline & $\{0.0401\}$ & $\{0.0222\}$ \\
\hline \multirow[t]{2}{*}{ FSIZE } & 0.183 & 0.061 \\
\hline & $\{0.0391\}$ & $\{0.2133\}$ \\
\hline \multirow[t]{2}{*}{ TANG } & 0.583 & -0.259 \\
\hline & $\{0.0099\}$ & $\{0.0649\}$ \\
\hline \multirow[t]{2}{*}{ GOP } & -0.002 & -0.004 \\
\hline & $\{0.4161\}$ & $\{0.7365\}$ \\
\hline R-Squared & 0.259 & 0.304 \\
\hline F-Value & 2.99 & 2.695 \\
\hline Prob (F-Stats) & $\{0.0337\}$ & $\{0.0217\}$ \\
\hline Equation & 1 & 2 \\
\hline Dependent Variable & DEBT & EQTY \\
\hline
\end{tabular}


Table 3 reports univariate and multivariate regressions results estimated to test the study hypotheses. The intercept, coefficients, p-values, R-squared, F-value and Prob(F-stats) are highlighted in each result.

The results in Panel A reveal that, independent boards have significant negative influence on debt usage among listed manufacturing firms in Nigeria. The negative influence is given by a coefficient of -0.209 , which is significant at the 0.05 level, given a $\mathrm{p}$-value $=0.03$. This shows that a percentage increase in board independence will lead to a significant decrease in debt capital utilization by about 21 percent.

Again, board size effect on debt capital level is given by a negative coefficient of -0.09 . This is interpreted to mean that board size affects debt capital negatively by about 9 percent, indicating that larger boards are associated with lower debt financing among sampled manufacturing firms on the NSE. However, the negative effect is not significant at the 0.05 alpha level, given the p-value of 0.42 . Hence, board size does not have a significant effect on debt capital.

CEO duality positively impacts the usage of debt financing, indicated by a regression coefficient of about 0.161. The positive impact of 16 percent explains that CEOs who assume dual roles in the governance of manufacturing companies prefer the use of debt in their capital structure, in order to embark upon all projects, they deem is of interest and benefit to them, since equity capital is limited. The positive coefficient is significant at the 0.05 level, given a p-value of 0.04 . thus, CEO duality has a significant impact on debt capital levels.

The controls results indicate that firm size and firm tangibility have positive and significant effects on debt capital levels, with the effect of firm size being 18.3 percent $(p=0.039)$ and that of firm tangibility being 58.3 percent $(p=0.009)$. The results however show that growth opportunity does have a negative and insignificant effect on debt financing $(-0.002, p=0.416)$, against apriori expectation of a positive and significant effect.

The R-squared value of 25.9 percent, and F-statistics value and (p-value) of $2.99(0.033)$ indicate that the model is fit and all variables jointly explain the dependent variable (debt capital).

Panel B reveal that independent boards have significant positive impact on equity capital levels among listed manufacturing firms in Nigeria. The positive impact given by a coefficient of 0.775 , which indicates a 77.5 percent impact, significant at the 0.05 level, given a $p$-value of 0.003 . This shows board independence significantly predict increase in equity capital levels by about 77.5 percent.

Also, board size effect on equity capital level is given by a negative coefficient of -0.0448 . This is interpreted to mean that board size affects equity capital negatively by about 4 percent, indicating that larger boards are associated with lower equity financing among sampled manufacturing firms on the NSE. However, the negative effect is not significant at the 0.05 alpha level, given the $p$-value of 0.522 . Hence, board size does not have a significant effect on equity capital.

Furthermore, CEO duality has a downward bias on equity capital levels, designated by a OLS regression coefficient of about -0.355 . The downward bias being a negative effect, explains about of 36 percent reduction in equity capital, which is significant at the 0.05 level, given a $p$-value of 0.02 . Thus, CEO duality has a significant negative bearing on equity capital levels.

The controls results indicate that only firm tangibility have negative and significant effect on equity capital levels, with an OLS coefficient effect of $-0.259(p=0.05)$. The results however show that firm size and growth opportunity do not have significant effects on equity capital structure, with their coefficients and (p-values) given as $0.061(0.213)$ and $-0.004(0.737)$ respectively.

The R-squared value of 30.4 percent, and F-statistics value and (p-value) of $2.695(0.0217)$ indicate that the model is fit and all variables jointly explain the dependent variable (equity capital).

Overall, there is significant relationship between corporate governance mechanisms and capital structure of manufacturing firms in Nigeria, based on the analysis from the Pearson correlation and the OLS regression analysis. 
Table 4: Cross Sectional Regression result for Hypotheses 2

\begin{tabular}{|c|c|c|c|}
\hline Variables & PANEL A & PANEL B & PANEL C \\
\hline \multirow[t]{2}{*}{ Intercept } & 0.041 & 0.188 & 78.788 \\
\hline & $\{0.7348\}$ & $\{0.8946\}$ & $\{0.0212\}$ \\
\hline \multirow[t]{2}{*}{ BIND } & 0.403 & 0.298 & 138.389 \\
\hline & $\{0.0007\}$ & $\{0.0381\}$ & $\{0.0002\}$ \\
\hline \multirow[t]{2}{*}{ BSIZE } & -0.013 & 0.099 & 12.146 \\
\hline & $\{0.0995\}$ & $\{0.2599\}$ & $\{0.2022\}$ \\
\hline \multirow[t]{2}{*}{ CEO } & 0.002 & -0.191 & -68.978 \\
\hline & $\{0.5909\}$ & $\{0.0419\}$ & $\{0.0130\}$ \\
\hline \multirow[t]{2}{*}{ DEBT } & -0.015 & -0.873 & 16.585 \\
\hline & $\{0.6846\}$ & $\{0.0069\}$ & $\{0.7169\}$ \\
\hline \multirow[t]{2}{*}{ EQTY } & 0.023 & 0.008 & 87.789 \\
\hline & $\{0.6962\}$ & $\{0.1438\}$ & $\{0.0000\}$ \\
\hline \multirow[t]{2}{*}{ FSIZE } & 0.049 & -0.156 & 17.756 \\
\hline & $\{0.0330\}$ & $\{0.5553\}$ & $\{0.5277\}$ \\
\hline \multirow[t]{2}{*}{ FAGE } & 0.019 & 0.003 & 8.338 \\
\hline & $\{0.0000\}$ & $\{0.9434\}$ & $\{0.9941\}$ \\
\hline R-Squared & 0.348 & 0.268 & 0.631 \\
\hline F-Value & 4.807 & 2.912 & 15.392 \\
\hline Prob (F-Stats) & $\{0.0002\}$ & $\{0.0500\}$ & $\{0.0000\}$ \\
\hline Equation & 3 & 4 & 5 \\
\hline Dependent Variable & ROA & FCF & MPS \\
\hline
\end{tabular}

Table 4 reports univariate and multivariate regressions results estimated to test the study hypotheses. The intercept, coefficients, p-values, R squared, F-value and Prob(F-stats) are highlighted in each result.

The results in Panel s A-C reveal that, independent boards (BIND) have significant impact on ROA, FCF and MPS. BIND has a positive and significant impact on ROA, RCF and MPS given by coefficient and ( $p$ values) of $0.403\{0.0007\}, 0.298\{0.0381\}$, and $138.389\{0.0002\}$ respectively. The significance of the effect of BIND on all; proxies of financial performance is at the 0.05 level. The results indicate that an independent board significantly increases profitability by about 40 percent, cash flows by about 30 percent and value by about 138 kobo.

The impact of Board size (BSIZE) on ROA, FCF and MPS are found to be negative for ROA (-0.013), and positive for both FCF (0.099) and MPS (12.146). However, at the 5 percent level of significance, BSIZE is found to exert no statistically significant impact on the financial performance variables, since the $p$-values of their coefficient of influence are $\{0.0995\},\{0.2599\}$ and $\{0.2022\}$ for ROA, FCF and MPS respectively. Thus, despite having an impact of $-1.3 \%, 9.9 \%$ and 12.14 kobo on ROA, FCF and MPS, FSIZE does not exert significant influence on financial performance.

The implications of CEO duality on financial performance is difference for all proxies of financial performance. CEO duality does not exert a significance influence on ROA at the 5\% alpha level, though its' ROA effect is documented as positive in the result (coefficient $=0.002, \mathrm{p}=0.5909$ ). CEO duality negatively impacts both FCF and MPS of the sampled manufacturing firms in Nigeria, with the effect being $-0.191\{0.0419\}$ on FCF, and $-68.978\{0.0130\}$ on MPS. The results documented above show that CEO duality is associated with decreased cash flows and market values of firm stocks by about $19 \%$ and 69 kobo respectively.

The overall result of the effect of corporate governance mechanisms on financial performance shows that there is a strong relationship among them.

Furthermore, the relations between capital structure and financial performance are revealed. The impact of DEBT on ROA and FCF are found to be negative, with the negative effect on ROA being statistically insignificant at the 0.05 level $(-0.015,(0.6846))$, and the negative effect on FCF being statistically significant at 
the 0.05 alpha level $(-0.873,(0.0069))$. DEBT is also shown to 0 have a positive impact of 16.585 kobo on MPS, howbeit, the positive impact is insignificant and negligible at the 5 percent level of significance (with $p=0.7169$ ). Overall, debt only has a significant, and negative impact on free cash flows, among the three financial performance proxies.

The effect of Equity (EQTY) on financial performance is positive for all proxies of financial performance, with coefficients of $0.023,0.008$ and 87.789 on ROA, FCF and MPS respectively. However, only the positive effect on MPS is significant at $5 \%$ alpha level, with a $p$-value $=0.000$. Thus, equity causes a negligible $2.3 \%$ increases in profit levels $(p=0.6962)$, an insignificant $0.8 \%$ rise in cash flows $(p=0.1438)$, and a substantial and significant 88 kobo increase in market price of manufacturing firms stock.

The results documented above show that capital structure predicts financial performance of manufacturing firms sampled in the study, thus leading to the rejection of null H3. It is upheld that there is a significant relationship between capital structure and financial performance of manufacturing firms in Nigeria.

The controls vectors results indicate that firm size and firm age have positive and significant effects on ROA, with effects of 4.9 percent $(p=0.033)$ and 2.9 percent $(p=0.000)$ from FSIZE and FAGE respectively.

From the regression analyses, the research therefore upholds that capital structure, corporate governance board characteristics and financial performance of manufacturing firms listed on the NSE are significantly related at the 0.05 level.

\section{CONCLUSION}

The results of this study submit that there is a significant relationship between corporate governance, capital structure and financial performance. Corporate governance has been as an essential tool for maintaining integrity of firms in the manufacturing industry, and hence strengthening their financial performance. Good corporate governance practices contribute to healthy business climate that encourages domestic and foreign investment which in turn improves the capital structure base and increases financial performance of these firms. The empirical study suggests solutions for listed manufacturing companies in enhancing firm performance through improving corporate governance and capital structure decisions.

Based on the empirical results, the lessons for CEO duality as a corporate governance mechanism are proposed. The listed manufacturing companies should focus on the role of CEO in managing and monitoring companies, and separate the role the role from chairing the board. The CEO should ideally not be the chairperson in the board. This will improve cash flows and firm value significantly, as the interest of the powerful CEO is moderated and curtailed.

The study also recommends that manufacturing companies maintain the current debt level in the industry, as excessive debt will decrease bottom lines, deplete their cash flows and diminish firm value (from increased cost of debt). They should widen their capital structure bases by investing more in risk-free investments.

\section{REFERENCES}

Abor, J. (2007), "Corporate governance and financing decisions of Ghanaian listed firms", Corporate Governance, Vol. 7, pp. 83-92.

Alexander, K (2006) 'Corporate governance and banks: The role of regulation in reducing the principal-agent problem', Journal of Banking Regulation, Vol.2,no.1, pp.17-40.

Anderson, R., Mansi, S. and Reeb, D. (2004), "Board characteristics, accounting report integrity and the cost of debt", Journal of Accounting and Economics, Vol. 37 No. 3, pp. 315-42.

Berger, A \& E. B. Dipatti. (2003).Capital Structure and Firm Performance: A New Approach to Testing Agency Theory and an Application to the Banking Industry. (January 2003). FEDS Working Paper No. 2002-54.

Bodaghi, A. \& Ahmadpour, A. (2010). The effect of cooperate governance and ownership structure on capital structure of Iranian listed companies.

Claessens, S., Fan, J. (2002). Corporate Governance in Asia: A Survey. International Review of Finance, vol. 3, no. 2, pp. 71-103.

Davis, J. H., Schoorman, F. D., \& Donaldson, L. (1997). Toward a stewardship theory of management. Academy of Management Review, 22(1), 20-47. http://dx.doi.org/10.5465/AMR.1997.9707180258

Driffield, N., Mahambare, V., \& Pal, S. (2007). How does ownership structure affect capital structure and firm value? Recent evidence from East Asia1.Economics of Transition, 15(3), 535-573.

Durnev and Kim (2003)

Friend, I., \& Lang, L. H. (1988). An empirical test of the impact of managerial self - interest on corporate capital structure. The Journal of Finance, 43(2), 271-281. Friend, I. \& Hasbrouck, J. (1988). Determinants of capital structure, in: A. Chen, ed., Research in Finance, 7, 119.

Garcia-Marco, T \& Robles-Fernandex, MD 2008, 'Risk-taking behaviour and ownership in the banking industry: The Spanish evidence ', Journal of Economics and Business, vol.60, no.4, pp. 332-354.

Gemmill, G. and Thomas, D.C. (2004), "Does governance affect the performance of closed end funds?", 
working paper, available at: www.ssrn.com (accessed 30 June 2004).

Gompers, P., Ishi, J. \&Metrick, A. (2003): Corporate governance and equity prices. Quarterly Journal of Economics, 118, 107-155.

Guo ,J., Ding, L., Sun ,J. (2010).”Company ownership and capital structure”.

Haniffa, R.M. and Cooke, T.E. (2002), Culture, corporate governance and disclosure in Malaysian corporations", ABACUS, Vol. 38 No. 3, pp. 317-49.

Hussainy , K \& Aljifri , K . (2010). Corporate governance mechanisms and capital structure in UAE. "in the agency theoretical framework". The Journal of Finance, 35(5): 1223-34.

Jandik, T. \& Rennie, C. G. (2008). The evolution of cooperate governance and firm performance in transition economies. European financial management, 1-53

Jensen, M. (1986), “Agency costs of free cash flow, corporate finance and takeover', American Economic Review, Vol. 76 No. 2, pp. 323-9.

Johnson, S., Boone, P., Breach, A. and Friedman, E. (2000), "Corporate governance in the Asian financial crisis", Journal of Financial Economics, Vol. 1, pp. 1-36.

Mohd et al., (2008) "Corporate governance, transparency and performance of Malaysian companies" Managerial Auditing Journal Vol. 23 No. 8, 2008 pp. 744-778

Nimalathasan, B., Valeriu B., (2010) Capital Structure and Its Impact on Profitability: A Study of Listed Manufacturing Companies in Sri Lanka (2010), Revista Tinerilor Economisti/The Young Economists Journal 13,55-61

Otnet, G. (2006). Ownership Structure and Capital Structure: Evidence from Jordanian Capital Market (19952003). Corporate Ownership \& Control 3: Issue 4.

Pfeffer, J. (1972). Size and composition of corporate boards of directors. The organization and its environment. Administrative Science Quarterly, 218-228. http://dx.doi.org/10.2307/2393956

Rehman, M. Ramiz and Rehman U. Muhammad A. and Raoof, A. (2010). Does corporate governance lead to a change in the capital structure?, American Journal of Social and Management Sciences.

Rob Bauer, Nadja Guenster and Roge' r Otten,(2004), Empirical evidence on corporate governance in Europe: The effect on stock returns, firm value and performance; Journal of Asset Management Vol. 5, 2, 91-104

Saad, N. M. (2010). Corporate Governance Compliance and the Effects to Capital Structure in Malaysia. International Journal of Economics and Finance, 2(1), 105-114. 89

Suto, M. (2003). Capital Structure and Investment Behavior of Malaysian firms in the 1990s: A Study of Corporate Governance before the Crisis. Corporate Governance 11: Number 1

Watt, R. L., \& Zimmerman J. L. (1986). Positive Accounting Theory: Englewood Cliffs. NJ: Prentice-Hall.

Wen, Y., Rwegasira, K. and Bilderbeek, J. (2002), "Corporate governance and capital structure decisions of Chinese listed firms", Corporate Governance: An International Review, Vol. 10 No. 2, pp. 75-83.

Zahra, S. A., \& Pearce, J. A. (1989). Boards of directors and corporate financial performance: A review and integrative model. Journal of management, 15(2), 291-334. 